\title{
PENGARUH KECEMASAN MATEMATIKA TERHADAP KEMAMPUAN PEMECAHAN MASALAH MATEMATIS SISWA SMP NEGERI SE-KECAMATAN BANYUASIN
}

\author{
Ika Septiarini ${ }^{1}$, Nila Kesumawati ${ }^{2}$, Jumroh $^{3}$ \\ ${ }^{1}$ Universitas PGRI Palembang, Indonesia, ikaseptiarini2717@gmail.com \\ ${ }^{2}$ Universitas PGRI Palembang, Indonesia, nilakesumawati@univpgri-palembang.ac.id \\ ${ }^{3}$ Universitas PGRI Palembang, Indonesia,jumrohdahlan@gmail.com
}

\begin{tabular}{l} 
ARTICLE INFORMATION \\
\hline Received: September 10, 2020 \\
Revised: November 20, 2020 \\
Available online: December 31, 2020 \\
KEYWORDS \\
Kecemasan matematika, \\
kemampuan pemecahan masalah \\
Math anxiety, problem solving skills \\
CORRESPONDENCE
\end{tabular}

Jumroh

E-mail:

jumrohdahlan@gmail.com

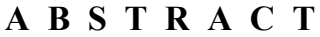

Penelitian ini bertujuan untuk mengetahui hubungan, pengaruh, dan seberapa besar pengaruh kecemasan matematika terhadap kemampuan pemecahan masalah matematis siswa SMP Negeri se-kecamatan Rambutan Banyuasin. Penelitian ini merupakan penelitian kuantitatif dengan menggunakan metode survey. Pengumpulan data dengan tes dan engket. Data yang dikumpulkan dianalisis dengan menggunakan teknik analisis korelasi yaitu uji normalitas, uji linieritas, dan uji korelasi. Dari hasil penelitian disimpulkan bahwa kecemasan matematika memiliki hubungan dan pengaruh terhadap kemampuan pemecahan masalah matematis siswa SMP Negeri se-kecamatan Rambutan Banyuasin.
\end{abstract}

This study aims to find out the relationship, influence, and how much influence of mathematical anxiety on the mathematical problem solving ability of smp negeri students in Rambutan Banyuasin sub-district. This research is quantitative research using survey method. Data collection with tests and engket. The data collected were analyzed using correlation analysis techniques namely normality test, linearity test, and correlation test. From the results of the study, it was concluded that mathematical anxiety has a relationship and influence on the mathematical problem solving ability of junior high school students in Rambutan Banyuasin sub-district.

\section{PENDAHULUAN}

Pembelajaran Matematika sangat dibutuhkan oleh semua peserta didik mulai dari sekolah yang paling dasar agar bisa menjadi modal peserta didik untuk bisa kemampuan berpikir logis, analitis, terstruktur, kritis, dan kreatif, serta mampu menjalin kerjasama (Permendiknas, Nomor 22, 2006:345). Sehingga kemampuan itu dibutuhkan agar siswa mendapatkan, memproses, dan menggunakan informasi untuk kehidupan sehari-hari pada kondisi yang tidak stabil, tidak pasti, dan persaingan. 


\section{Journal of Mathematics Science and Education}

ISSN (Print) 2623-2375 | ISSN (Online) 2623-2383 |

DOI : https://doi.org/10.31540/jmse.v3i1.951

Penerbit : LP4MK STKIP PGRI Lubuklinggau

Sasaran umum pembelajaran Matematika berdasarkan yang dirumuskan dalam Permendiknas Nomor 22 (2006:346) yaitu: (1) mengerti konsep matematika, menjelaskan keterlibatan antar konsep dan mengaplikasikan konsep atau algoritma, secara luwes, tepat, dan simpel dalam penyelesaian masalah; (2) memakai pemikiran pada pola dan sifat, memakai manipulasi matematika tersusun sebagai generalisasi, merangkai bukti, atau memaparkan gagasan dan pernyataan matematika; (3) menyelesaikan masalah yang mencakup kemampuan mengartikan masalah, mendesain model matematika, menyelesaikan model dan memperkirakan solusi yang diperoleh; (4) menjabarkan gagasan dengan simbol, tabel, diagram, atau media lain untuk menjabarkan keadaanatau masalah; serta (5) memiliki sikap menghormati manfaat dari matematika dalam lingkungan sehari-hari, yaitu mempunyai rasa ingin tahu, perhatian, dan keinginan dalam mempelajari matematika, serta sikap tekun dan percaya diri dalam pemecahan masalah.

Dari tujuan umum pembelajaran Matematika tersebut maka dapat disimpulkan bahwa kemampuan pemecahan masalah merupakan kemampuan yang harus dimiliki siswa. Akan tetapi, faktanya banyak siswa yang masih lemah dalam pembelajaran matematika. Hal ini dapat dilihat dari data Kemdikbud tentang hasil ujian nasional SMP tahun 2017, ditingkat nasional rata-rata hasil UN matematika hanya 50,34, cukup rendah dibandingkan tiga mata pelajaran lainnya. Untuk daerah Sumatera Selatan sendiri, rata-rata hasil UN matematika hanya 45,18. Sedangkan di SMP Negeri 22 Palembang, rendahnya hasil belajar siswa dilihat dari rata-rata nilai matematika siswa kelas VII tahun ajaran 2016/2017 selama peneliti menjalani masa Praktik Pengalaman Lapangan (PPL). Dari sekian banyaknya siswa hanya beberapa siswa yang mendapatkan nilai mencapai standar ketuntasan minimal. Terutama disaat peneliti meminta siswa untuk memberikan jawaban terhadap soal yang diberikan di papan tulis, kebanyakan siswa mengeluh tidak mampu dalam menyelesaikan soal yang hampir mirip dengan contoh yang telah dijelaskan sebelumnya.

Menurut Slameto (2010: 54-72) ada beberapa faktor yang mempengaruhi hasil belajar siswa, yaitu faktor intern dan faktor ekstern. Faktor intern meliputi faktor jasmaniah, psikologis, dan kelelahan. Sementara itu faktor ekstern meliputi faktor keluarga, sekolah, dan masyarakat yaitu yang berkaitan dengan lingkungan luar diri siswa tersebut. Faktor yang berhubungan dengan kegiatan belajar mengajar di sekolah seperti materi pembelajaran yang terlalu kaku dan kurang diminati, metode pembelajaran yang baku dan selalu tertuju pada guru mengakibatkan siswa tidak aktif sehingga siswa tidak mempunyai kesempatan untuk berfikir matematik. 


\section{Journal of Mathematics Science and Education \\ ISSN (Print) 2623-2375 | ISSN (Online) 2623-2383 । \\ DOI : https://doi.org/10.31540/jmse.v3i1.951 \\ Penerbit : LP4MK STKIP PGRI Lubuklinggau}

Terkait dengan faktor penyebab tersebut, selama menjalani masa PPL di SMP Negeri 22 Palembang, peneliti mendapatkan informasi dari hasilwawancara dengan beberapa siswa tentang kesan selama belajar matematika, mereka menganggap matematika itu pelajaran yang paling sulit.Siswa banyak mengeluhkan pusing susahnya memproses materi matematika yang dijelaskan. Dari hasil pengamatan peneliti, sebagian banyak siswa tidak semangat dan menunjukkan keikutsertaan yang sedikit selama belajar matematika. Sebagian siswa selalu tidak mau saat diminta untuk menyelesaikan soal di papan tulis atau menjawab pertanyaan dari guru. Kondisi dua arah yang diinginkan (guru dan siswa sama-sama aktif) juga tidak tersampaikan di kelas. Siswa kebanyakan berbicara dengan teman sebangku, sibuk dengan hal lain yang ada di meja, dan mengganggu teman yang lain selama proses belajar dilaksanakan.Hanya sedikit dari mereka yang tampak memperhatikan pelajaran. Namun berdasarkan pejelasan rekan-rekan PPL, tanda yang sama tidak nampak ketika kegiatan pembelajaran di mata pelajaran yang lain, apalagi mata pelajaran sosial.

Pada kenyataannya menunjukkan rendahnya kemampuan pemecahan masalah matematika diperburuk dengan realita ketidaksenangan siswa terhadap matematika itu sendiri, namun sejauh ini penelitian yang telah banyak dijalankan lebih tertuju pada metode atau strategi belajar mengajar saja dan tidak banyak yang melaksanakan penelitian secara mendalam terhadap faktor internal siswa kepada kemampuan pemecahan masalah. Selain itu mata pelajaran yang sukar dipelajari dan menakutkan adalah sebagian besar anggapan siswa terhadap matematika. Maka dari itu, kecemasan matematika (mathematics anxiety) dapat dikenal sebagai rasa takut yang muncul hingga dapat menyebabkan kecemasan saat siswa sedang belajar atau berinteraksi dengan matematika.

Berdasarkan uraian tersebut, maka dilakukan penelitian terkait pengaruh kecemasan matematika terhadap kemampuan pemecahan masalah matematis siswa SMP Negeri se-kecamatan Rambutan Banyuasin. Tujuan dilakukan penelitian tersebut adalah untuk melihat hubungan seberapa besar pengaruh antara kecemasan matematika dan kemampuan pemecahan masalah matematis siswa.

\section{METODE}

Metode yang digunakan dalam penelitian ini adalah metode survey. Penelitian ini mengambil populasi dua sekolah dan dari masing-masing sekolah diambil satu kelas sebagai sampel. Variabel bebas dalam penelitian ini adalah kecemasan matematika dan yang menjadi variabel terikat dalam penelitian ini adalah kemampuan pemecahan masalah matematis. Penelitian ini dilaksanakan dalam satu kali pertemuan setiap sekolah jadi berjumlah dua kali pertemuan pada semester genap 


\section{Journal of Mathematics Science and Education \\ ISSN (Print) 2623-2375 | ISSN (Online) 2623-2383 | \\ DOI : https://doi.org/10.31540/jmse.v3i1.951 \\ Penerbit : LP4MK STKIP PGRI Lubuklinggau}

2019/2020. Diambil sampel masing-masing kelas VIII dari tiap sekolah ada 24 siswa dari SMP Negeri 3 Rambutan dan 23 siswa dari SMP Negeri 4 Rambutan.

Pengumpulan data dalam penelitian ini menggunakan teknik tes dan angket. Instrumen yang digunakan berupa soal essay berisikan sebanyak lima butir soal dan dua puluh satu angket yang harus dikerjakan siswa. Sebelum digunakan instrument tes dan angket telah diuji terlebih dahulu sehingga instrument tes dan angket layak digunakan sebagai alat pengumpul data. Daya pembeda soal yang digunakan instrument pada penelitian ini diuji coba tergolong cukup baik. Tingkat kesukaran pada instrument yang digunakan tergolong mudah dan sedang sehingga mampu mewakili kondisi siswa. Selain itu, instrument yang digunakan memiliki validitas dan reliabilitas yang cukup tinggi.

Data yang dikumpulkan diolah menggunakan cara analisis statistik. Berdasarkan hasil analisis data, diketahui bahwa data berdistribusi normal dan juga berpola linier. Pengujian hipotesis dilakukan dengan cara melakukan uji korelasi.

\section{HASIL DAN PEMBAHASAN}

\section{Kecemasan Matematika}

Ashcraft dan Faust (dalam Susanti dan Rohmah, 2011) memberikan artian bahwa kecemasan matematika adalah perasaan terpaksa, kegelisahan bahkan kekhawatiran yang tercampur dengan kesalahan yang luar biasa pada angka dan memecahkan soal matematika. Kecemasan matematika merupakan reaksi emosional terhadap matematika berdasarkan pada pengalaman yang tidak menyenangkan di masa lalu yang merugikan pembelajaran di masa depan (Freedman, 2006:1). Begitupun dalam situasi bervariasi baik itu dalam kehidupan sehari-hari maupun akademik yang memiliki perasaan ketegangan dan kecemasan yang mengganggu manipulasi masalah matematika adalah kecemasan matematika menurut Richardson dan Suinn (Mahmood dan Khatoon, 2011:170). Dikarenakan suatu sebab di masa lalu yang berpengaruh pada masa sekarang yang menimbulkan rasa cemas yang disertai rasa takut dan tegang disaat berhadapan dengan pembelajaran matematika merupakan kesimpulan yang diambil dari pengertian-pengertian diatas.

Beberapa penyebab yang bisa mengakibatkan munculnya kecemasan matematika menurut Trujillo dan Hadfield (dalam Anita, 2014: 127) yaitu sebagai berikut: 


\section{Journal of Mathematics Science and Education \\ ISSN (Print) 2623-2375 | ISSN (Online) 2623-2383 | \\ DOI : https://doi.org/10.31540/jmse.v3i1.951 \\ Penerbit : LP4MK STKIP PGRI Lubuklinggau}

a. Faktor Kepribadian

Rasa takut akan kemampuan diri, kepercayaan diri rendah yang menyebabkan nilai harapan yang rendah, pengalaman masa lalu yang tidak mengenakkan terutama dalam pelajaran matematika yang menimbulkan trauma merupakan factor kepribadian (psikologis atau emosional).

b. Faktor Lingkungan Sosial

Di keluarga terutama orang tua yang terkadang memaksakan anaknya untuk pandai dalam pembelajaran matematika, karena matematika dipandang sebagai sebuah ilmu yang memiliki nilai prestise. Kemudian suasana kelas menjadi menakutkan yang disebabkan oleh cara guru mengajar, model dan metode yang diterapkan oleh guru, merupakan faktor yang dialami disaat proses pembelajaran matematika.

c. Faktor Intelegtual

Dalam penelitian yang dilaksanakan oleh Ashcraft dan Kirk (dalam Johnson, 2003) mengarah pada adanya korelasi antara kecemasan matematika dan kemampuan verbal atau talenta serta tingkat kecerdasan. Faktor yang lebih tertuju pada bakat dan tingkat pemikiran yang dimiliki siswa disebut sebagai faktor intelegtual atau pengaruh yang bersifat psikologis.

Sedangkan menurut Nurmila (2016: 53) ada beberapa aspek yang dapat dilihat pada tabel dibawah ini.

a. Manifestasi kognitif yang tidak terkendali seperti sulit berkonsentrasi dalam belajar, dapat berpikir dengan tenang dalam pembelajaran

b. Manifestasi afektif yang tidak terkendali seperti merasa takut ketika menghadapi ujian, tidak percaya diri dalam menghadapi pelajaran matematika

c. Perilaku motorik yang tidak terkendali seperti nampak pucat saat ditunjuk ke papan tulis menyelesaikan soal, sering keringatan jika mengerjakan soal matematika

\section{Kemampuan Pemecahan Masalah Matematis}

Berpikir, menyelesaikan masalah dan membuat sesuatu yang baru adalah kegiatan yang kompleks dan berkaitan erat satu sama lain. Setiap masalah biasanya tidak dapat diselesaikan tanpa berpikir, dan banyak masalah membutuhkan pemecahan yang baru bagi satuan orang atau kelompok. Sebaliknya, menghasilkan sesuatu (benda-benda, gagasan-gagasan) yang baru bagi seseorang, menciptakan sesuatu, itu mencakup pemecahan masalah (Slameto, 2013: 142). 


\section{Journal of Mathematics Science and Education \\ ISSN (Print) 2623-2375 | ISSN (Online) 2623-2383 । \\ DOI : https://doi.org/10.31540/jmse.v3i1.951 \\ Penerbit : LP4MK STKIP PGRI Lubuklinggau}

Kegiatan dasar untuk kehidupan individu yaitu menyelesaikan suatu masalah. Karena kumpulan dari masalah-masalah yang harus diselesaikan merupakan dasar kehidupan seseorang. Secara umum aspek-aspek kemampuan pemecahan masalah matematis adalah pemahaman, penggunaan strategi dan prosedur matematis, dan komunikasi. Aspek pemahaman tertuju pada kemampuan mengelompokkan data atau informasi yang dibutuhkan untuk memecahkan masalah dan membuat model matematika dari masalah. Aspek strategi dan prosedur tertuju pada kemampuan memilih dan menerapkan strategi pemecahan masalah dan melakukan langkah matematis. Sedangkan aspek komunikasi tertuju pada kemampuan memaparkan penjelasan terhadap strategi, konsep-konsep terkait, dan langkah matematis yang dilakukan, memanfaatkan representasi matematis, terminologi, dan notasi matematis, dan mengartikan dan menjelaskan (Mahmudi, 2010: 5).

Konsep Dewey (dalam Slameto, 2013: 143) tentang berpikir itu menjadi dasar untuk pemecahan masalah adalah sebagai berikut :

a) Adanya kesulitan yang dirasakan atau kesadaran akan adanya masalah

b) Masalah itu diperjelas dan dibatasi

c) Mencari informasi atau data dan kemudian data itu diorganisasikan

d) Mencari hubungan-hubungan untuk merumuskan hipotesis-hipotesis, kemudian hipotesishipotesis itu dinilai, diuji agar dapat ditentukan untuk diterima atau ditolak

e) Penerapan pemecahan terhadap masalah yang dihadapi sekaligus berlaku sebagai pengujian kebenaran pemecahan tersebut untuk dapat sampai pada kesimpulan

Dari penjabaran di atas dapat disimpulkan bahwa kemampuan pemecahan masalah matematis adalah kemampuan atau kesanggupan seseorang memecahkan suatu masalah yang dihadapi dengan penggunaan strategi dan prosedur yang berbeda pada setiap siswa dalam memecahkan permasalahan matematika.

Adapun indikator kemampuan pemecahan masalah menurut Satriyani (2013:16) yang memiliki beberapa aspek yaitu

a. Memahami masalah seperti mengidentifikasi informasi yang diketahui dan mengidentifikasi apa yang ditanyakan

b. Merencanakan pemecahan masalah seperti merencanakan langkah-langkah penyelesaian dengan memilih konsep (rumus) yang akan digunakan dan membuat sketsa gambar

c. Melaksanakan rencana penyelesaian masalah seperti menjalankan rencana penyelesaian sesuai dengan langkah-langkah yang telah direncanakan 


\section{Journal of Mathematics Science and Education \\ ISSN (Print) 2623-2375 | ISSN (Online) 2623-2383 । \\ DOI : https://doi.org/10.31540/jmse.v3i1.951 \\ Penerbit : LP4MK STKIP PGRI Lubuklinggau}

d. Memeriksa kembali terhadap solusi

seperti memeriksa kembali solusi yang diperoleh dan memberikan alasan yang relevan untuk solusi yang diperoleh

\section{Pengaruh Kecemasan Matematika terhadap Kemampuan Pemecahan Masalah Matematis}

Kecemasan matematika baik itu dalam kehidupan sehari-hari ataupun dalam akademik yaitu sebagai perasaan tertekan dan cemas yang mengganggu manipulasi masalah matematika didefinisikan berdasarkan Richardson dan Suinn yang dikutip oleh Mahmood (2011). Sedangkan Blazer (2011) mengatakan "Math anxiety is a defined as negative emotions that interface with the solving of mathematical problem" yang artinya kecemasan matematika adalah emosi negatif yang berhubungan dengan penyelesaian masalah matematika.

Hubungan negatif antara kecemasan matematika terhadap kemampuan pemecahan masalah matematis dimaksudkan jika pada tingkat kecemasan tinggi maka tingkat kemampuan pemecahan masalah rendah dan sebaliknya jika tingkat kecemasan rendah maka tingkat kemampuan pemecahan masalah semakin tinggi ini berdasarkan Aunurrofiq dan Junaedi (2017:165). Adapun dengan Ashcraft dan Faust (dalam Susanti dan Rohmah, 2011) memberikan artian bahwa kecemasan matematika adalah perasaan terpaksa, kegelisahan bahkan kekhawatiran yang tercampur dengan kesalahan yang luar biasa pada angka dan memecahkan soal matematika.Dari penjabaran diatas maka dapat disimpulkan bahwa kecemasan memiliki pengaruh dan hubungan negatif terhadap kemampuan pemecahan masalah matematika.

Berdasarkan hasil penelitian yang telah dilakukan oleh peneliti di dua sekolah di kecamatan Rambutan Banyuasin yang total sampel berjumlah 47 orang siswa, menunjukkan 22 orang siswa cenderung mengalami kecemasan rendah, sedangkan 25 orang siswa cenderung mengalami kecemasan tinggi. Jika dilihat dari nilai rata-rata tes kemampuan pemecahan masalah matematis siswa yang berkecemasan rendah yaitu 48,09 sedangkan nilai rata-rata tes kemampuan pemecahan masalah siswa yang berkecemasan tinggi yaitu 39,06. Dilihat dari hasil tes tersebut makan nilai kemampuan pemecahan masalah siswa yang berkecemasan rendah lebih tinggi dari nilai kemampuan pemecahan masalah siswa yang berkecemasan tinggi. Maka tingkat kecemasan matematika bisa menjadi salah satu faktor yang mempengaruhi tinggi atau rendahnya nilai tes kemampuan pemecahan masalah matematis siswa.

Dari hasil yang telah didapat dan dianalisis maka kecemasan matematika memiliki pengaruh terhadap kemampuan pemecahan masalah matematis yang berkisar 24,56 \% dari data uji korelasi. Begitupun hasil yang telah dapat dikatakan bahwa hasil korelasi yaitu -0,24566 dengan tanda negatif, 


\section{Journal of Mathematics Science and Education \\ ISSN (Print) 2623-2375 | ISSN (Online) 2623-2383 | \\ DOI : https://doi.org/10.31540/jmse.v3i1.951 \\ Penerbit : LP4MK STKIP PGRI Lubuklinggau}

ini berarti kecemasan matematika memiliki hubungan yang signifikan terhadap kemampuan pemecahan masalah matematis. Tanda negatif dimaksud memiliki hubungan yang berlawanan arah, artinya jika tingkat kecemasan matematika tinggi maka kemampuan pemecahan masalah matematis bernilai rendah atau kurang baik namun sebaliknya jika kecemasan matematika rendah maka nilai kemampuan pemecahan masalah matematis sangat baik. Kecemasan matematika memiliki pengaruh dan hubungan yang signifikan terhadap kemampuan pemecahan masalah matematis karena berdasarkan dari data yang didapat besar nilai korelasi yaitu 0,246 dan nilai thitung 1,756 lebih besar dari pada $t_{\text {tabel }}$. Jadi dapat disimpulkan tinggi rendahnya kemampuan pemecahan masalah berhubungan dengan tinggi rendahnya tingkat kecemasan matematika siswa.

Hal ini senada dengan penelitian yang dilakukan oleh Satriyani (2015) menunjukkan bahwa kecemasan matematika berpengaruh sebesar 26,19\% terhadap kemampuan pemecahan masalah matematis, dan penelitian yang dilakukan oleh Junaedi dan Aunurrofiq (2017) juga menunjukkan pengaruh kecemasan matematika sebesar $24 \%$ terhadap kemampuan pemecahan masalah matematis. Dengan kata lain, dapat disimpulkan bahwa kecemasan matematika memiliki pengaruh terhadap kemampuan pemecahan masalah.

\section{KESIMPULAN}

Berdasarkan hasil penelitian dan pembahasan dapat disimpulkan bahwa terdapat hubungan antara tingkat kecemasan matematika terhadap kemampuan pemecahan masalah matematis siswa SMP Negeri se-kecamatan Rambutan Banyuasin. Dan juga ada pengaruh kecemasan matematika terhadap kemampuan pemecahan masalah matematis siswa SMP Negeri se-kecamatan Rambutan Banyuasin. Adapun saran dari penelitian ini yaitu: untuk guru lebih memperhatikan proses pembelajaran baik itu materi, metode pembelajaran, strategi pembelajaran, lingkungan pembelajran dan lain sebagainya yang lebih menyenangkan dan menarik agar peserta didik tidak merasa tertekan atau mengalami kecemasan yang berlebihan terhadap matematika. Begitupun dengan siswa hendaknya mampu mengendalikan kecemasan yang ada pada dirinya sehingga dapat meningkatkan hasil belajar dan juga untuk lebih mempersiapkan diri dalam menerima materi yang akan diajarkan oleh guru. 


\section{DAFTAR RUJUKAN}

Ashcraft, Mark H. 2002. Math Anxiety: Personal, Educational, and Cognitive Consequences(online). (http://www.mccc.edu/ jenningh/Courses/documents/math_anxiety.pdf, diakses 18 Februari 2017)

Anurrofiq, M dan Iwan Junaedi. 2017. Kecemasan Matematik Siswa dalam Menyelesaikan Soal-soal Pemecahan Masalah.

Depdiknas. 2006. Peraturan Menteri Pendidikan Nasional Republik Indonesia Nomor 22 tahun 2006 tentang Standar Isi untuk Satuan Pendidikan Dasar dan Menengah.Jakarta: depdiknas

Freedman, Ellen. 1997-2006. Do You have Math Anxiety? A Self Test (online). (http://www.pearsoncustom.com/mdc_algebra/math_anxiety_material.pdf, diakses 19 Februari 2017)

Hartono. 2015. Statistik untuk Penelitian. Pekanbaru Riau: Pustaka Pelajar

Hamzah, Ali. 2014. Evaluasi Pembelajaran Matematika. Jakarta: Raja Grafindo Persada

Khatoon, T. \& Mahmood, S. (2010). Mathematics Anxiety Among Secondary School Students in India and its Relationship to Achievement in Mathematics. European Journal of Social Science, 16 (1), 75-86.

Riduwan. 2013. Belajar Mudah Penelitian untuk Guru-Karyawan dan Peneliti Pemula. Bandung: Alfabeta

Satriyani. 2016. Pengaruh Kecemasan Matematika (Mathematics Anxiety) dan Gender Terhadap Kemampuan Pemecahan Masalah Matematis Siswa(online). (repository.uinjkt.ac.id/dspace/bitstream/123456789/32047/3/SATRIYANI-FITK.pdf, diakses 18 Februari 2017)

Slameto, 2013. Belajar dan Faktor-faktor yang Mempengaruhi. Jakarta: Rineka Cipta

Yanti, Dwi dan Herma Yunita (2020). "Kecemasan Matematika dan Self Efficacy dalam melakukan Pembuktian Matematika”. Journal of Mathematics Science and Education

Zakaria, E., Nordin, N. M. (2008). "The Effects of Mathematics Anxiety on Matriculation Student as Related to Motivation and Achievement”. Eurasia Journal of Mathematics, Science, \& Technology Eductaion. 4 (1), 27-30. 